\title{
Books also Received
}

(The inclusion of a title does not preclude the possibility of subsequent review. Items received, other than those assigned for review, are ultimately incorporated into the collection of the Wellcome Library.)

Karen Buhler-Wilkerson, No place like home: a history of nursing and home care in the United States, Baltimore and London, Johns Hopkins University Press, 2001, pp. xvi, 293, illus., $£ 31.00$ (hardback 0-80186598-0).

Kenneth Collins, Be well! Jewish health and welfare in Glasgow, 1860-1914, East Linton, Tuckwell Press, 2001, pp. xiv, 194,

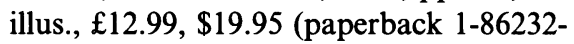
129-9).

David L Cowen, Pharmacopoeias and related literature in Britain and America, 1618-1847, Variorum Collected Studies Series: CS700, Aldershot, Ashgate, 2001, pp. ix, 296, illus., $£ 55.00$ (hardback 0-86078-842-3).

Marcos Cueto, Culpa y coraje: historia de las politicas sobre el VIHISIDA en el Perú, Lima, Consorcio de Investigación Económica y Social/Facultad de Salud Pública y Administración, Universidad Peruana Cayetano Heredia, 2001, pp. 170 (paperback 9972-804-16-X).

Philip D Curtin, Migration and mortality in Africa and the Atlantic world, 1700-1900, Variorum Collected Studies Series, Aldershot, Ashgate, 2001, pp. 360, $£ 59.50$ (hardback 0-86078-833-4).

Peter C English, Old paint: a medical history of childhood lead-paint poisoning in the United States to 1980, New Brunswick and London, Rutgers University Press, 2001, pp. xv, 254, £57.95 (hardback 0-81352987-5).
Andreas Frewer and Volker Roelcke (eds), Die Institutionalisierung der Medizinhistoriographie: Entwicklungslinien vom 19. ins 20. Jahrhundert, Stuttgart, Franz Steiner, 2001, pp. 267, $€ 40.00$ (hardback 3515-07849-5).

Eilidh Garrett, Alice Reid, Kevin Schürer and Simon Szreter, Changing family size in England and Wales: place, class and demography, 1891-1911, Cambridge Studies in Population, Economy and Society in Past Time, Cambridge University Press, 2001, pp. xxiii, 526, $£ 60.00, \$ 90.00$ (hardback 0521-80153-2).

\section{Marijke Gijwijt-Hofstra and Roy Porter} (eds), Cultures of neurasthenia: from Beard to the first world war, Clio Medica 63, Wellcome Series in the History of Medicine, Amsterdam and New York, Rodopi, 2001, pp. iv, 407, illus., $€ 95.00, \$ 89.00$ (hardback 90-420-0931-4), $€ 37.00, \$ 34.00$ (paperback 90-420-0921-7).

Sumit Guha, Health and population in South Asia from earliest times to the present, London, Hurst, 2001, pp. vii, 178, $£ 25.00$ (hardback 1-85065578-2).

Danielle Gourevitch and Marie-Thérèse Raepsaet-Charlier, La Femme dans la Rome antique, Paris, Hachette, 2001, pp. 301, illus., $€ 22.00$ (paperback 2-01-2353310-X).

Dan Healey, Homosexual desire in revolutionary Russia: the regulation of sexual and gender dissent, Chicago and London, University of Chicago Press, 2001, pp. xvi, 392 , illus., $\$ 40.00$ (hardback 0-226-32233-5).

Elisabeth Hsu (ed.), Innovation in Chinese medicine, Needham Research Institute Series, No. 3, Cambridge University Press, pp. xv, 426, $£ 55.00, \$ 80.00$ (hardback 0-52180068-4). 


\section{Books also Received}

Margaret Humphreys, Malaria: poverty, race, and public health in the United States, Baltimore and London, Johns Hopkins University Press, 2001, pp. xi, 196, $£ 28.50$ (hardback 0-8018-6637-5).

O P Jaggi, Medicine in India: modern period, vol. 9, part 1, of History of Science, Philosophy and Culture in Indian Civilization, Project of History of Indian Science, Philosophy and Culture, New Delhi, Oxford University Press, 2000, pp. xxvi, 355, £35.00 (hardback 0-19-565126-X).

Ian Maclean, Logic, signs and nature in the Renaissance: the case of learned medicine, Ideas in Context, Cambridge University Press, 2002, pp. xvi, 407, illus., $£ 45.00$ (hardback 0-521-80648-8).

Reginald Passmore, Fellows of Edinburgh's College of Physicians during the Scottish Enlightenment, Edinburgh, Royal College of Physicians, 2001, pp. viii, 132, illus., $£ 10.00$. Orders to: Royal College of Physicians, 9 Queen Street, Edinburgh EH2 1JQ, Scotland.

Judith Robinson, Noble conspirator: Florence $S$ Mahoney and the rise of the National Institutes of Health, Washington, DC, Francis Press, 2001, pp. xiv, 342, illus., $\$ 28.00$ (hardback 0-9665051-4-X).

Lutz Sauerteig, Krankheit, Sexualität, Gesellschaft. Geschlechtskrankheiten und Gesundheitspolitik in Deutschland im 19. und frühen 20. Jahrhundert, Medizin, Gesellschaft und Geschichte No. 12, Stuttgart, Franz Steiner, pp. 542, $€ 85.00$ (paperback 3-515-07393-0).

Johan A Schioldann, In commemoration of the centenary of the death of Carl Lange.
The Lange theory of 'periodical depressions'. $A$ Landmark in the history of lithium therapy, Adelaide, Adelaide Academic Press, 2001 , pp. x, 200, illus. (paperback 09578585-0-7).

Mary Lynn Stewart, For health and beauty: physical culture for Frenchwomen, 1880s-1930s, Baltimore and London, Johns Hopkins University Press, 2001, pp. xii, 274, illus., $£ 29.50$ (hardback 0-8018-6483-6).

Ilkka Taipale, et al.(eds), War or health? $A$ reader, London and New York, Zed Books in association with Physicians for Social Responsibility (Finland), 2002, pp. xix, 652, $£ 55.00, \$ 75.00$ (hardback 1-85649950-2), £16.95, \$29.95 (paperback 1-85649951-0).

Kathleen A Tobin, The American religious debate over birth control, 1907-1937, Jefferson, NC, and London, McFarland, 2001, pp. vi, 226, £37.95 (paperback 078641081-7). Distributed in the UK by Shelwing Ltd, 4 Pleydell Gardens, Folkestone, Kent CT20 2DN.

Farokh Erach Udwadia, Man and medicine: a history, New Delhi, Oxford University Press, 2000, pp. xvi, 496, illus., $£ 31.50$ (hardback 0-19-565457-9).

Jane Wood, Passion and pathology in Victorian fiction, Oxford University Press, 2001, pp. viii, 232, $£ 45.00$ (hardback 0-12818760-2), £13.99 (paperback 0-19-9247137).

David Wright, Mental disability in Victorian England: the Earlswood Asylum, 1847-1901, Oxford, Clarendon Press, 2001, pp. xii, $244, £ 40.00$ (hardback 0-19-9246394). 